\title{
Assessment of combining ability in purple corn parents under line $x$ tester mating design using GGE biplot
}

\author{
NURUL MUFIDAH ${ }^{1,2, v}$, ARIFIN NOOR SUGIHARTO ${ }^{3, \vee v}$, BUDI WALUYO $^{3}$ \\ ${ }^{1}$ Graduate Program, Faculty of Agriculture, Universitas Brawijaya. Jl. Veteran, Malang 65145, East Java, Indonesia \\ ${ }_{2}^{2}$ PT. BISI International, Tbk. Jl. Raya Pare-Wates Km. 13, Sumberagung, Plosoklaten, Kediri 64175, East Java, Indonesia. Tel./fax. +62-54-392624, \\ remail: mufida0990@gmail.com \\ ${ }^{3}$ Department of Agronomy, Faculty of Agriculture, Universitas Brawijaya. Jl. Veteran, Malang 65145, East Java, Indonesia. Tel.: +62-341-551611, \\ •vemail: sugiharto.noor@gmail.com
}

Manuscript received: 9 August 2021. Revision accepted: 27 September 2021.

\begin{abstract}
Mufidah N, Sugiharto AN, Waluyo B. 2021. Assessment of combining ability in purple corn parents under line $\times$ tester mating design using GGE biplot. Biodiversitas 22: 4545-4554. One strategy to increase corn quality is the development of new corn cultivars by incorporating the character of nutritional content. The study aims to obtain information on the combining ability of purple corn lines as well as determine the best parental lines for purple corn hybrid development using the GGE biplot approach. This study used 24 hybrids generated from crossings of 8 purple corn lines with 3 testers, which were crossed using a line $\times$ tester mating design. Plant performance was assessed using a randomized block design of three replications. The F-test was used to assess and test the experiment variance. The combining ability of purple corn lines was examined using the GGE biplot method. The result showed that the GGE biplot approach successfully identified the best combiner and combinations generated between purple corn lines and non-purple corn lines. Purple corn lines P1Y1 had the best general combining ability for fresh ear yield and total anthocyanin content, meanwhile, P1Y2 had the best general combining ability in most of the agronomic traits, namely ear diameter, shelled ear weight, number of grains row ${ }^{-1}$, and as well as total anthocyanin content. These 2 lines were also identified as the best parent chosen in the best combination in this study.
\end{abstract}

Keywords: GGE biplot, heterosis, purple corn, hybrid parent analysis, anthocyanin

Abbreviations: GGE: Genotype + Genotype by Environment; GCA: General Combining Ability; SCA: Specific Combining Ability

\section{INTRODUCTION}

Purple corn is a food crop that is still relatively unknown in Indonesia due to limited consumption. Purple corn has more anthocyanin content than other varieties of corn (Georgiana et al. 2019). This variety can be produced not only by crossing purple corn with other purple corn but also by crossing with non-purple corn since the dominant behavior of the $P l$ gene can generate a hybrid of purple corn (Hossain et al. 2019). One initiative to increase corn quality is to develop a new corn cultivar by incorporating kernel color characteristics and combining it with other specialty corn such as waxy and sweet corn.

Purple corn had higher anthocyanins and strong antioxidant activity than other corn varieties. Its kernels contain anthocyanins ranging from 54.00 to $115.05 \mathrm{mg} 100$ $\mathrm{g}^{-1}$ seed (Moreno et al. 2005). To increase the edible level, a cross between purple corn and other edible corn is supposed to yield purple corn with a good texture and taste. Waxy corn has a chewy feel with a hint of sweetness. The texture of glutinous rice is affected by the endosperm's starch content in the form of amylopectin (Boonlertnirun and Boonlertnirun 2018), while sweet corn has endosperm that produces provitamin A carotenoids (Khamphasan et al. 2020). Pigmented corn contain anthocyanins that represents a promising class of antioxidants found naturally in plants that may increase nutritional quality ( Magaña-Cerino et al.
2020)), where pigment formation is primarily determined by genetic factors (Harakotr et al. 2016).

Purple corn production has the potential to maximize economic value while still producing nutritious corn-based foods. Aside from pigments from the appearance of the corn kernels, the key goals of most corn breeding systems are high yield and early maturity. To achieve high-yielding purple corn hybrids with superior color and nutritional quality, research into the ability of these lines must be conducted. This potential can be investigated by studying the General Combining Ability (GCA), Specific Combining Ability (SCA), and other properties so that the desired properties can be effectively chosen for hybrid development (Hosana et al. 2015). Line $\times$ tester analysis is one of method that has been widely used to identify genotype capabilities as potential hybrid parents, and several previous studies have been performed to measure the combining ability of parental lines corn using line $\times$ tester analysis (Arbha et al. 2013; Ruswandi et al. 2015a; Mutimaamba et al. 2020).

The Genotype by Environment Interaction Biplot (GGE Biplot) approach commonly has been used to investigate a plant's combining ability and line potential (Kannababu et al. 2017; Khalil dan Raziuddin 2017; Ahmed et al. 2019). This technique is suitable for data originating from the line $\times$ tester crosses based on the data structure (Ruswandi et al. 2015b; Kahriman et al. 2016). The GGE biplot will provide clear explanations of the source of variation, making it 
easier for breeders to choose the desired genotype (Yan 2001). The GGE biplot analysis on the line $\times$ tester has also been applied to other crops such as sorghum (Kannababu et al. 2017), sunflower (Ahmed et al. 2019), corn (Ruswandi et al. 2015b; Momeni et al. 2020). Unfortunately, there has been limited study into how GGE-biplot may be used to identify the best parent lines with good combining ability in physiological aspects such as anthocyanin content. This study aims to obtain information on the combining ability of purple-seed-colored corn lines and to identify the best lines and testers as well as to identify potential combinations that can be used in the development of hybrid purple corn.

\section{MATERIALS AND METHODS}

\section{Plant materials}

This study used 8 purple corn lines and 3 non-purple corn lines ( 2 waxy corn and 1 sweet corn) as a tester, which were then crossed between the two corn groups using the line $\times$ tester mating design, resulting in 24 purple corn hybrids. The crossing was carried out by using three plants each as female and male parents for each combination. To avoid outcross, the silk and tassels from all of the plants subjected to cross were covered with polypropylene woven cloth paper bags. Crosses were carried out in the 2020 dry season (August-November) while hybrid evaluations were carried out in the 2021 rainy season (January-March). The research was carried out in Plosoklaten District, Kediri, East Java, Indonesia.

\section{Experimental design and field evaluation}

The experimental design used to evaluate plant performance was a randomized block design with 3 replications and 35 genotypes ( 24 hybrids and 11 parent genotypes) as treatment. Each experimental plot consists of 3 rows with a $5 \mathrm{~m}$ length of each row $(65 \mathrm{~cm}$ between rows and $20 \mathrm{~cm}$ between plants in the row). Fertilization was carried out three times during the growing period. The basal fertilizer of NPK (15-15-15) at a rate of $250 \mathrm{~kg} \mathrm{ha}^{-1}$ was applied 7 days after planting (DAP), the second and the third fertilizer were applied with Urea $200 \mathrm{~kg} \mathrm{ha}^{-1}$ at 21 25 DAP and 42-45 DAP respectively. The traits observed included fresh ear yield per hectare $\left(\mathrm{t} \mathrm{ha}^{-1}\right)$, plant height $(\mathrm{cm})$, fresh harvest maturity (dap-day after planting), number of grains row $^{-1}$, ear diameter $(\mathrm{cm})$, shelled ear weight $(\mathrm{g})$, and total anthocyanins content $\left(\mathrm{mg} 100 \mathrm{~g}^{-1}\right)$.

The total anthocyanins content was measured using a pH-differential method (Sutharut dan Sudarat 2012). A total of 2 grams of pericarp samples extracted from corn dry kernels with sandpaper were dissolved in a tube containing $10 \mathrm{ml}$ of ethanol and vortexed for 30 seconds. The solution was then heated in a water bath at $60^{\circ} \mathrm{C}$ for 20 minutes and vortexed for 30 seconds every 10 minutes. The solution was then centrifuged at $4500 \mathrm{rpm}$ for 10 minutes. The solvent was then poured into a calibrated $50 \mathrm{ml}$ test tube. The centrifuge residue is then diluted with $10 \mathrm{ml}$ of ethanol, and the solvent and residue separation procedure can be repeated up to 5 times until the solvent is colorless. Prepare two of $10 \mathrm{~mL}$ volumetric flask and added with 1 $\mathrm{mL}$ of solvent solution each. Two types of buffer were prepared such as $\mathrm{pH} 1,0$ and $\mathrm{pH} 4.5$, with the first volumetric flask was added with $9 \mathrm{~mL}$ of potassium chloride to obtain buffer with $\mathrm{pH} 1.0$, and the second flask was added with $9 \mathrm{~mL}$ of sodium acetate for $\mathrm{pH} 4.5$ buffer. The dilution was then allowed to equilibrate for 15 minutes. Measure the absorbance of each dilution against an empty cell filled with pure water at 510 and $700 \mathrm{~nm}$. Water blanks are used to take absorbance measurements. Calculate the absorbance of the diluted sample (A) as follows: using grain pericarp extract. The equation is:

$$
\mathrm{A}=\left(\mathrm{A}_{510}-\mathrm{A}_{700}\right)_{(\mathrm{pH} 1.0)}-\left(\mathrm{A}_{510}-\mathrm{A}_{700}\right)_{(\mathrm{pH} 4.5)}
$$

The monomeric anthocyanin pigment concentration in the original sample was then converted to $\mathrm{mg}$ of total anthocyanin content $100 \mathrm{~g}^{-1}$ sample using the following formula:

Monomeric Anthocyanin Pigmen

$\left(\mathrm{mg} . \mathrm{L}^{-1}\right)=(\mathrm{A} \times \mathrm{MW} \times \mathrm{DF} \times 1000) /(\varepsilon \times 1)$

Where MW is the molecular weight, DF is the dilution factor, and $\varepsilon$ is the molar absorptivity, calculate pigment content as cyanidin-3-glucoside, where $\mathrm{MW}=449.2$ and $\varepsilon=26,900$.

\section{Data analysis}

The variance was calculated using the line $\times$ tester analysis described by Singh and Chaudary (Singh dan Chaudary 1977), The significance of the mean square of combining ability was tested using the F-test. The combining ability of each corn line was analyzed using the GGE biplot method (Ruswandi et al. 2015b; Arifin et al. 2018). This GGE biplot line $\times$ tester uses the mathematical model described by Ruswandi et al. (2015b) as follows:

$$
Y_{i j}-b_{j}=a_{1} e_{i 1} h_{j 1}+a_{2} e_{i 2} h_{j 2}+e_{i j}
$$

Where, $Y_{i j}$ is the combination genotype value (pure lines or F1 hybrid) between line $\mathrm{i}$ and tester $\mathrm{j}$ for a certain trait; $b_{j}$ is the mean value of all combinations with testers $j$, $\mathrm{a}_{1}$, and $\mathrm{a}_{2}$ are the singular values for PC1 and PC2. ei $i_{1}$ and $\mathrm{ei}_{2}$ are the eigenvectors PC1 and PC2, respectively for line $\mathrm{i}$ (entry); hj $\mathrm{j}_{1}$ and $\mathrm{hj}_{2}$ are the eigenvectors PC1 and PC2 for tester $\mathrm{j}$, respectively; $\mathrm{e}_{\mathrm{ij}}$ is the residue model of inbred $\mathrm{i}$ and tester $\mathrm{j}$. Biplot graphics were obtained from Genstat Edition 20 , with no data transformation, and no scaling, while centering was applied at tester focus. Heterobeltiosis analysis was performed to identify which hybrid can outperform its parent. The calculation was described by Khamphasan et al. (2020) using the following formula:

$$
\text { Heterobeltiosis }(\%)=\frac{F 1-\text { Better Parent }}{\text { Better Parent }} \times 100
$$

\section{RESULTS AND DISCUSSION}

The analysis of variance showed that the lines had a significant effect on the variance of fresh ear yield (FEY), ear diameter (ED), shelled ear weight (SEW), and total anthocyanins content (TAC). On the other hand, the tester also had a significant effect on the variety of FEY and the 
fresh ear maturity (FEM). The interaction between lines and the tester had a significant effect on the variance of all observed traits except for SEW and TAC. Although the line and tester only have a significant effect on a few traits, the interaction between the two can provide significant variance in F1.

\section{General combining ability effects of lines}

GGE Biplot analysis through the Average Tester Coordinate (ATC) can be used to analyze the GCA and SCA effect on lines. Based on Table 1, it can be seen that the total variation of each trait varies from $82.26 \%$ to $99.06 \%$. This shows that the observational data is sufficient to be used in the GGE-Biplot analysis. The GCA effect of a line can be determined by its combined value with the tester mean. Thus, the GCA effect of the lines can be estimated by projecting these lines on the ATC abscissa (Yan and Hunt 2002). The small circle on the ATC abscissa represents the mean of the tester, which is determined by the mean values of PC1 and PC2 of all testers (Yan and Kang 2003).

The GCA of the lines for each trait can be seen in Table 1 where there are several differences in the effect of the best GCA by the lines on each trait. Based on Figure 1.A and Table 1, it can be concluded that the best-combined effect on the trait of FEY ( $\mathrm{t} \mathrm{ha}^{-1}$ ) is owned by the purple corn line P1Y1, while the genotype with the lowest GCA is P2Y1 and P2W. Whereas the P1Y2 line had the best GCA on the PH, ED, SEW, and TAC, the P1Y3 line had the best-combining effect on the FEM. Meanwhile, the P2Y3 line had the best combining ability effect on the NGR.
Based on Table 2, we can see also that the P2W line has the lowest combining effect on all the traits observed except for FEM, where the P1W line was identified as having the lowest combining effect on this trait.

\section{Specific combining ability effect of lines}

The conventional approach to combining ability analysis (line $\times$ tester) can only describe the SCA that was analyzed on the appearance of the hybrid performance (crosses), but this is only the residual value resulting from the reduction in the value of the GCA effect and does not include any explanation of the parent abilities (Yan et al. 2003). A biplot analysis can be used to determine if the parent used has a strong SCA effect for generating future hybrids to explain the effect of SCA on the parent. According to Yan and Hunt (2002), SCA effects can be identified from a biplot graph based on the projected distance of the entries (lines) in the ATC ordinate. It can also represent the tendency of an entry (lines) to produce superior hybrids against a particular tester.

According to Figure 1.C, the P1Y1 line has the best SCA effect in FEY, led by P1Y2, while the P1Y2 line has the best SCA effect in TAC (Figure 1.D). In terms of PH, the P2W lines had the greatest SCA effect, followed by P2Y3, P2Y2, P1Y2, P1Y3, and P1Y1. The P2W lines were found to have the best SCA on corn ED, led by P2Y2 and $\mathrm{P} 1 \mathrm{Y} 2$. The best SCA on the SEW was found in P1Y2, followed by P1Y1. For the FEM, the best line that has SCA was P1W followed by P1Y1. But if the objective is to obtain a hybrid with medium-late maturity the best SCA would be P2Y1 followed by P1Y3.

Table 1. Total variance and GCA effect ranking order of lines based on Average Tester Coordinate Graphic of GGE biplot

\begin{tabular}{lcl}
\hline \multicolumn{1}{c}{ Traits } & Total variance $(\%)$ & \multicolumn{1}{c}{ Lines GCA effect } \\
\hline FEY & 99.06 & $\mathrm{P} 1 \mathrm{Y} 1>\mathrm{P} 1 \mathrm{Y} 2>\mathrm{P} 1 \mathrm{Y} 3>\mathrm{P} 2 \mathrm{Y} 2 \approx \mathrm{P} 2 \mathrm{Y} 3>\mathrm{P} 1 \mathrm{~W}>\mathrm{P} 2 \mathrm{Y} 1 \approx \mathrm{P} 2 \mathrm{~W}$ \\
$\mathrm{PH}$ & 82.26 & $\mathrm{P} 1 \mathrm{Y} 2>\mathrm{P} 2 \mathrm{Y} 3 \approx \mathrm{P} 1 \mathrm{Y} 3>\mathrm{P} 1 \mathrm{Y} 1>\mathrm{P} 2 \mathrm{Y} 1>\mathrm{P} 2 \mathrm{Y} 2>\mathrm{P} 1 \mathrm{~W}>\mathrm{P} 2 \mathrm{~W}$ \\
FEM & 93.77 & $\mathrm{P} 1 \mathrm{Y} 3 \approx \mathrm{P} 2 \mathrm{Y} 1>\mathrm{P} 2 \mathrm{~W}>\mathrm{P} 2 \mathrm{Y} 2>\mathrm{P} 1 \mathrm{Y} 2 \approx \mathrm{P} 2 \mathrm{Y} 3>\mathrm{P} 1 \mathrm{Y} 1>\mathrm{P} 1 \mathrm{~W}$ \\
$\mathrm{ED}$ & 88.79 & $\mathrm{P} 1 \mathrm{Y} 2>\mathrm{P} 2 \mathrm{Y} 1 \approx \mathrm{P} 1 \mathrm{Y} 3 \approx \mathrm{P} 1 \mathrm{Y} 1>\mathrm{P} 1 \mathrm{~W}>\mathrm{P} 2 \mathrm{Y} 2>\mathrm{P} 2 \mathrm{Y} 3>\mathrm{P} 2 \mathrm{~W}$ \\
$\mathrm{SEW}$ & 93.34 & $\mathrm{P} 1 \mathrm{Y} 2>\mathrm{P} 1 \mathrm{Y} 1>\mathrm{P} 2 \mathrm{Y} 3>\mathrm{P} 2 \mathrm{Y} 2>\mathrm{P} 1 \mathrm{~W} \approx \mathrm{P} 2 \mathrm{Y} 1 \approx \mathrm{P} 1 \mathrm{Y} 3>\mathrm{P} 2 \mathrm{~W}$ \\
NGR & 90.52 & $\mathrm{P} 2 \mathrm{Y} 3>\mathrm{P} 1 \mathrm{Y} 2>\mathrm{P} 2 \mathrm{Y} 1 \approx \mathrm{P} 1 \mathrm{Y} 1>\mathrm{P} 2 \mathrm{Y} 2 \approx \mathrm{P} 1 \mathrm{Y} 3>\mathrm{P} 1 \mathrm{~W}>\mathrm{P} 2 \mathrm{~W}$ \\
TAC & 93.88 & $\mathrm{P} 1 \mathrm{Y} 2>\mathrm{P} 1 \mathrm{~W} \approx \mathrm{P} 1 \mathrm{Y} 1>\mathrm{P} 1 \mathrm{Y} 3>\mathrm{P} 2 \mathrm{Y} 2 \approx \mathrm{P} 2 \mathrm{Y} 1 \approx \mathrm{P} 2 \mathrm{Y} 3>\mathrm{P} 2 \mathrm{~W}$ \\
\hline
\end{tabular}

Note: FEY: Fresh Ear Yield (ton ha ${ }^{-1}$ ); SEW: Shelled Ear Weight (g); ED: Ear Diameter $(\mathrm{cm})$; NGR: Number of Grain Row ${ }^{-1}$; PH: Plant Height (cm); FEM: Fresh Ear Maturity (Days After Planting); TAC: Total Anthocyanin Content (mg $\left.100 \mathrm{~g}^{-1}\right)$

Table 2. Variance analysis of agronomic traits and yield component of purple corn parental and F1

\begin{tabular}{llllllll}
\hline Source of variation & FEY & SEW & ED & NGR & PH & FEM & TAC \\
\hline Replication & $3.93 \mathrm{~ns}$ & $135.38 \mathrm{~ns}$ & $0.69 * *$ & $7.85 \mathrm{~ns}$ & $269 \mathrm{~ns}$ & $1.44 \mathrm{~ns}$ & $1263.39 * *$ \\
Genotype & $23.05 * *$ & $1888.14 * *$ & $0.16 * *$ & $20.26 * *$ & $605.73 * *$ & $37.41 * *$ & $12987.74 * *$ \\
Parents & $28.34 * *$ & $1928.91 * *$ & $0.11 * *$ & $8.63 \mathrm{~ns}$ & $659.79 * *$ & $45.52 * *$ & $26492.28 * *$ \\
Parents Vs F1 & $96.27 * *$ & $20423.77 * *$ & $1.16 * *$ & $155.60 * *$ & $7363.58 * *$ & $20.4 * *$ & $79.59 \mathrm{~ns}$ \\
F1 & $17.57 * *$ & $1064.52 * *$ & $0.13 * *$ & $19.44 * *$ & $288.41 * *$ & $34.63 * *$ & $7677.42 * *$ \\
Lines & $30.04 * *$ & $2028.87 * *$ & $0.21 *$ & $23.5 \mathrm{~ns}$ & $277.68 \mathrm{~ns}$ & $24.44 \mathrm{~ns}$ & $13208.61 *$ \\
Testers & $30.37 *$ & $428.16 \mathrm{~ns}$ & $0.1 \mathrm{~ns}$ & $32.28 \mathrm{~ns}$ & $93.48 \mathrm{~ns}$ & $188.39 * *$ & $7124.34 \mathrm{~ns}$ \\
Lines x Testers & $9.51 * *$ & $673.25 \mathrm{~ns}$ & $0.1 * *$ & $15.57 * *$ & $321.62 * *$ & $17.75 * *$ & $4990.83 * *$ \\
Error & 3.51 & 443.4 & 0.02 & 4.30 & 118.73 & 1.04 & 23.85 \\
CV & 11.20 & 12.42 & 3.73 & 7.89 & 5.57 & 1.51 & 4.50 \\
\hline
\end{tabular}

Note: **: Significant level of 1\%, *: Significant level of 5\%; ns: not significant; FEY: Fresh Ear Yield (ton ha ${ }^{-1}$ ); SEW: Shelled Ear Weight (g); ED: Ear Diameter (cm); NGR: Number of Grain Row ${ }^{-1}$; PH: Plant Height $(\mathrm{cm})$; FEM: Fresh Ear Maturity (Days After

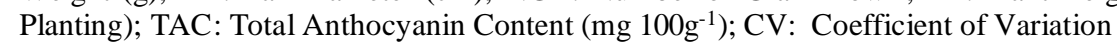



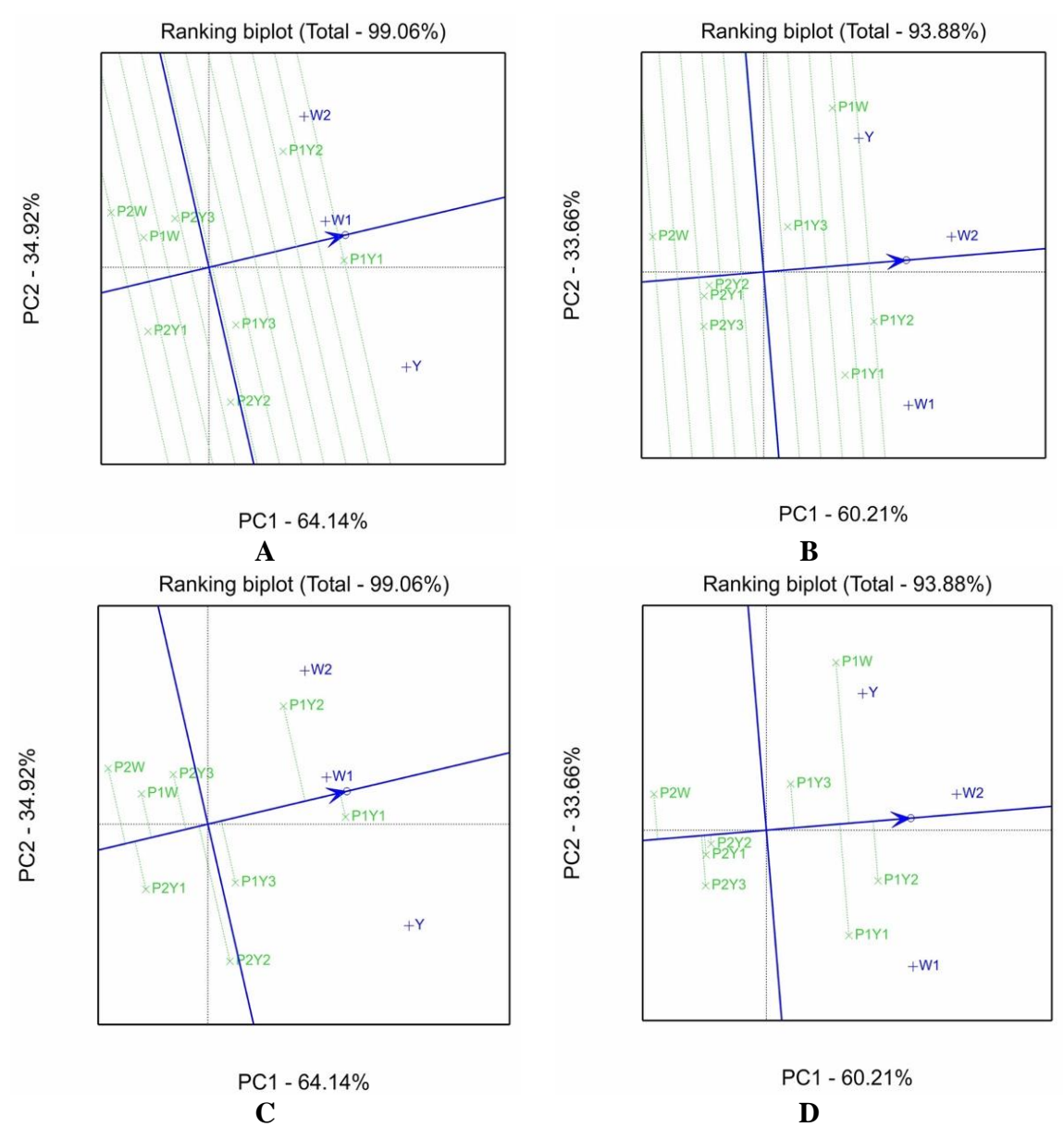

Figure 1. ATC view-based line $\times$ tester (A-D), the arrow represents the average testers. Line (P-Y-) is in green and tester (W1, W2, Y) is in the blue letter. The ATC abscissa is the approximate GCA effect of the lines for FEY(A), and TAC (B) and the SCA effect of the lines for FEY (C), and TAC (D)

\section{Best tester for general combining ability}

GGE Biplot analysis can be used to identify the best tester for predicting a genotype's GCA. To find the best tester, the tester should be placed as close to the ATC abscissa as possible, and the vector should be the longest of all testers to be the most discriminating among all entries (genotype) (Yan et al. 2003). GGE biplot analysis, in addition to identifying the best tester, can also classify the best lines by shifting the analysis's attention (ATC) to the genotype (Figure 2). Based on Figure 2, it can be inferred that, although none of the testers are positioned next to the ATC abscissa, the W1 tester is the better option since it is nearest to the concentric circle. Meanwhile, the W1 line, which was the furthest away from the concentric circle, was the better choice of tester for FEM. This is because maturity preference is negative, with early maturity preferred over late maturity. The same should be applicable for PH. The best tester was identified by the same lines (W1) for hybrids with short plant stature and Y for hybrids with medium-high plant stature based on the biplot analysis. The $\mathrm{Y}$ line is the best tester for the ear diameter trait because it matches the two conditions. The W1 line was the best tester on the SEW, positioned close to the ATC abscissa. Meanwhile, for NGR of the W2 line was defined as the best tester with a similar condition, although the vector was somewhat shorter than the Y line.

\section{Best crosses among hybrid}

GGE-Biplot analysis may assist in determining the best hybrid based on the polygonal view created by the entry/groove farthest from the origin; this shape is also known as the convex hull. The perpendicular line intersects the polygonal line that begins at the origin and then divides into sections (sectors). According to Yan and Hunt (2002), testers in the same sector would also share the same line pair. The best hybrids based on FEY can be identified in Figure 3.A, where the $\mathrm{W} 1$ and $\mathrm{Y}$ testers are located in the P1Y1 sector. This demonstrates that the $\mathrm{W} 1$ and $\mathrm{Y}$ testers are the most compatible with the P1Y1. The W2 tester is in the same sector as the P1Y2 line, indicating that when combined with the W2 tester, the P1Y2 line would produce high-yield hybrids. The absence of a tester in the P2W, $\mathrm{P} 2 \mathrm{Y} 1$, and P2Y2 lines sectors means that no tester is ideal for these lines to produce a high-yield hybrid when compared with the hybrid performance generated from P1Y1 and P1Y2 (Table 3).

On the biplot graph of TAC (Figure 3.B), the W1 tester is located in the P1Y1 line sector, indicating that the W1 
tester is the ideal partner for the P1Y1 line in developing hybrids with high TAC that make the highest TAC among combinations which are $204.14 \mathrm{mg}^{100 \mathrm{~g}^{-1}}$ (Table 3). Although the P1Y2 line was located in a different sector from the W1 tester, the P1Y2 location is nearly placed in the P1Y1 sector border that will certainly give a potential combination also with the W1 tester. Similarly, the best combination for the W2 tester is $\mathrm{P} 1 \mathrm{Y} 2$ and $\mathrm{P} 1 \mathrm{~W}$ since it is located between the P1Y2 and P1W sectors (Figure 3.B). This combination produces 170.95 and $186.40 \mathrm{mg} 100 \mathrm{~g}^{-1}$ of TAC respectively, this is the highest TAC compare to other combinations using W2 tester (Table 3). Meanwhile, the $\mathrm{Y}$ testers combine well with $\mathrm{P} 1 \mathrm{~W}$ lines to generate a high TAC hybrid (Figure 3.B and Table 3). GGE-biplot also reveals that the P2Y2, P2Y1, P2Y3, and P2W lines do not match all testers well (Figure 3.B). This means that when these lines are combined with all testers, they will most likely generate hybrids with low TAC. Based on the same analysis, it can be seen that each trait has a good combination of lines and testers. In terms of $\mathrm{PH}$, the crosses $\mathrm{P} 2 \mathrm{Y} 3 \times \mathrm{W} 2$ and $[\mathrm{P} 1 \mathrm{Y} 2, \mathrm{P} 1 \mathrm{Y} 3, \mathrm{P} 1 \mathrm{Y} 1] \times[\mathrm{W} 1, \mathrm{Y}]$ will generate hybrid corn with a tall plant posture.
Meanwhile, hybrids with short plant postures can be generated by crossing $\mathrm{P} 2 \mathrm{~W}, \mathrm{P} 2 \mathrm{Y} 2, \mathrm{P} 1 \mathrm{~W}$, and $\mathrm{P} 2 \mathrm{Y} 1$ lines with both testers.

The best hybrid pair for generating a big ear hybrid are $[\mathrm{P} 1 \mathrm{Y} 2] \times[\mathrm{W} 1, \mathrm{Y}]$ and $\mathrm{P} 1 \mathrm{Y} 3 \times \mathrm{W} 2$. Because of its similarity to the sector line separating the two tester sectors, the P1Y1 line matches well with all testers. The $\mathrm{W} 1$ and $\mathrm{W} 2$ testers are found in the P1Y2 and P1Y1 lines in the SEW trait. This suggests that the best combination for SEW is the W1 and W2 testers with the P1Y1 and P1Y2 lines (Table 3). The best combination based on NGR is obtained from the cross of $\mathrm{P} 2 \mathrm{Y} 3 \times[\mathrm{W} 2, \mathrm{Y}]$ and $\mathrm{P} 2 \mathrm{Y} 2 \times$ $\mathrm{W} 1$. The P1Y1 and P2Y1 lines are located in the same sector as the W2 and Y testers, but since the location of the two lines is near to the origin, it is considered no significant difference between the combination of these lines for all testers. For FEM, The combination of the P1Y3, P2Y1, and the W2, Y tester results in a medium late hybrid. This also occurs when P2W and $\mathrm{W} 1$ are combined. If the breeding aims to produce an early mature hybrid, then the previously mentioned line and tester combination should be considered carefully.
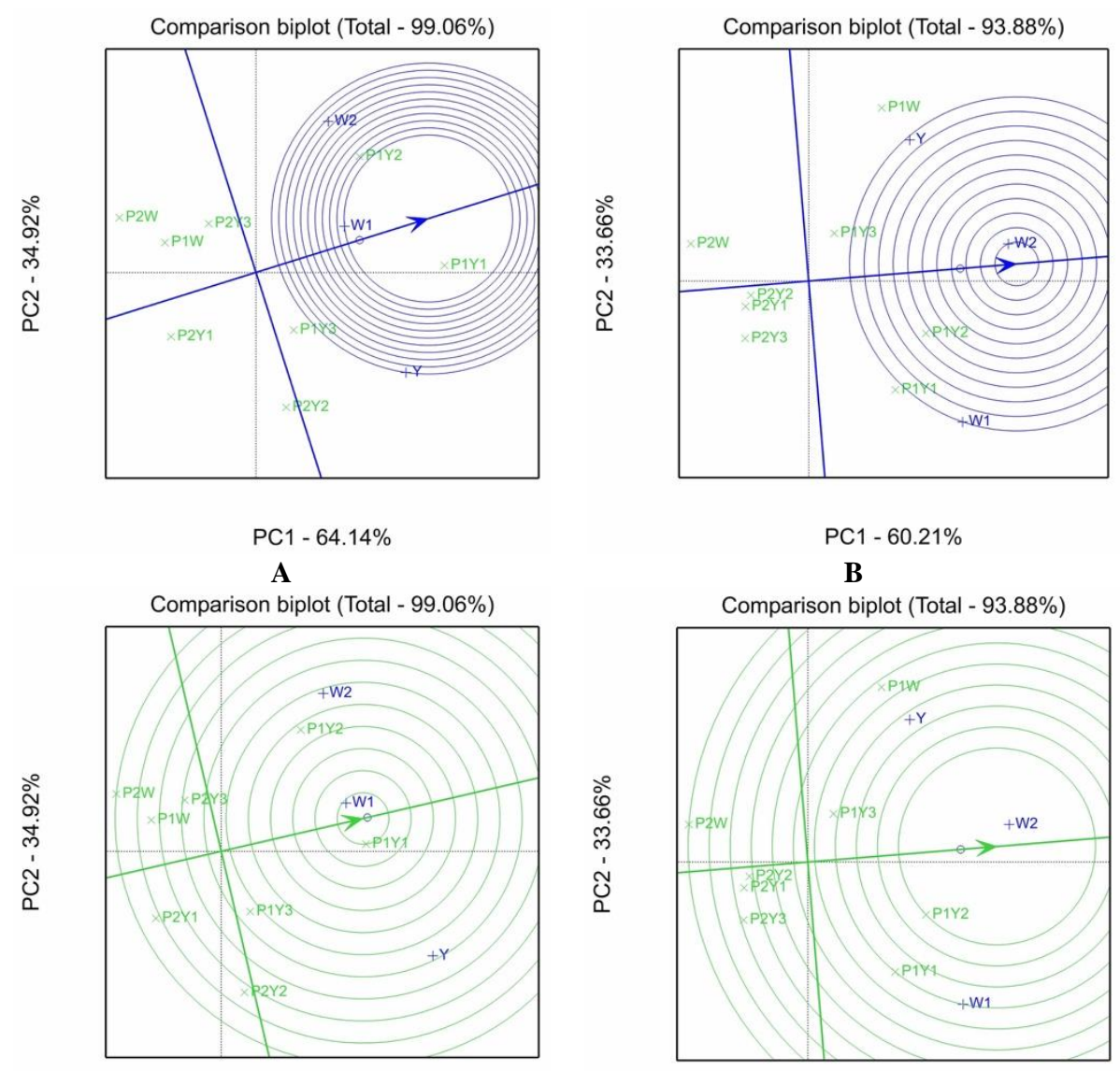

PC1 $-64.14 \%$

C

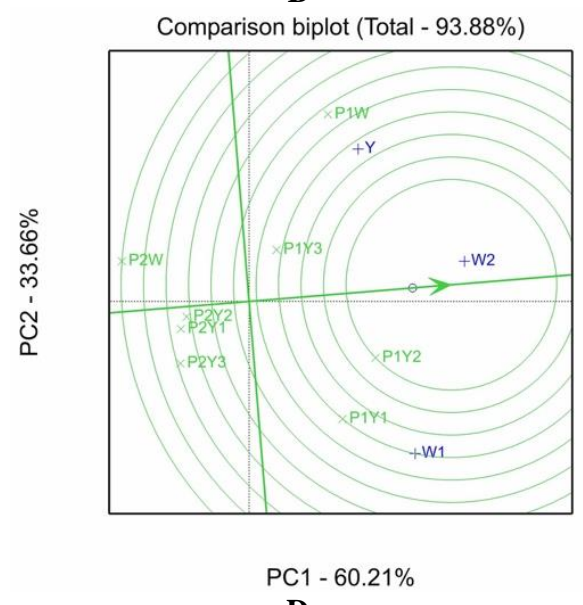

D

Figure 2. Comparison plot for tester of FEY (A), and TAC (B) traits and comparison plot for lines of FEY (C), and TAC (D) traits. Lines (P-Y-) are in green and tester (W1, W2, Y) are in blue letters. The arrow represents the average tester (A-B) and lines (C-D) 
Table 3. Mean performance of lines combination for several traits observation based on GGE-biplot

\begin{tabular}{|c|c|c|c|c|c|c|c|}
\hline Hybrids & FEY & SEW & ED & NGR & $\mathbf{P H}$ & FEM & TAC \\
\hline $\mathrm{P} 1 \mathrm{Y} 1 \times \mathrm{W} 1$ & 19.31 & 192.83 & 4.17 & 27.57 & 203.07 & 64.67 & 204.14 \\
\hline $\mathrm{P} 1 \mathrm{Y} 1 \times \mathrm{W} 2$ & 19.01 & 189.92 & 4.34 & 26.28 & 191.73 & 63.33 & 151.33 \\
\hline $\mathrm{P} 1 \mathrm{Y} 1 \times \mathrm{Y}$ & 23.04 & 212.42 & 4.30 & 29.02 & 204.33 & 69.67 & 74.10 \\
\hline $\mathrm{P} 1 \mathrm{Y} 2 \times \mathrm{W} 1$ & 19.43 & 200.50 & 4.35 & 28.60 & 218.73 & 66.33 & 197.46 \\
\hline $\mathrm{P} 1 \mathrm{Y} 2 \times \mathrm{W} 2$ & 20.41 & 198.83 & 4.23 & 25.32 & 204.93 & 64.00 & 170.95 \\
\hline $\mathrm{P} 1 \mathrm{Y} 2 \times \mathrm{Y}$ & 19.15 & 205.37 & 4.40 & 29.74 & 210.87 & 68.00 & 110.21 \\
\hline $\mathrm{P} 1 \mathrm{Y} 3 \times \mathrm{W} 1$ & 17.39 & 154.57 & 4.11 & 27.08 & 208.53 & 64.67 & 107.29 \\
\hline $\mathrm{P} 1 \mathrm{Y} 3 \times \mathrm{W} 2$ & 15.44 & 171.77 & 4.43 & 23.17 & 196.20 & 68.67 & 140.90 \\
\hline $\mathrm{P} 1 \mathrm{Y} 3 \times \mathrm{Y}$ & 20.33 & 181.44 & 4.29 & 28.36 & 205.80 & 73.67 & 112.93 \\
\hline $\mathrm{P} 1 \mathrm{~W} \times \mathrm{W} 1$ & 15.70 & 184.30 & 4.30 & 21.64 & 203.47 & 64.67 & 74.10 \\
\hline $\mathrm{P} 1 \mathrm{~W} \times \mathrm{W} 2$ & 16.37 & 177.53 & 4.27 & 26.11 & 210.40 & 63.33 & 186.40 \\
\hline $\mathrm{P} 1 \mathrm{~W} \times \mathrm{Y}$ & 16.11 & 155.50 & 3.87 & 29.30 & 186.40 & 66.33 & 174.09 \\
\hline $\mathrm{P} 2 \mathrm{Y} 1 \times \mathrm{W} 1$ & 15.59 & 172.27 & 4.11 & 26.80 & 195.20 & 67.00 & 91.43 \\
\hline $\mathrm{P} 2 \mathrm{Y} 1 \times \mathrm{W} 2$ & 13.93 & 159.83 & 4.16 & 27.34 & 195.53 & 67.00 & 90.80 \\
\hline $\mathrm{P} 2 \mathrm{Y} 1 \times \mathrm{Y}$ & 17.59 & 182.97 & 4.40 & 29.14 & 198.40 & 74.00 & 48.22 \\
\hline $\mathrm{P} 2 \mathrm{Y} 2 \times \mathrm{W} 1$ & 15.98 & 178.23 & 3.94 & 29.40 & 188.27 & 62.33 & 94.56 \\
\hline $\mathrm{P} 2 \mathrm{Y} 2 \times \mathrm{W} 2$ & 13.89 & 151.79 & 4.32 & 25.71 & 206.80 & 64.67 & 87.25 \\
\hline $\mathrm{P} 2 \mathrm{Y} 2 \times \mathrm{Y}$ & 21.63 & 202.13 & 3.87 & 24.98 & 196.07 & 74.33 & 61.79 \\
\hline $\mathrm{P} 2 \mathrm{Y} 3 \times \mathrm{W} 1$ & 16.09 & 181.55 & 3.89 & 28.19 & 193.53 & 68.67 & 99.57 \\
\hline $\mathrm{P} 2 \mathrm{Y} 3 \times \mathrm{W} 2$ & 17.50 & 183.19 & 4.12 & 29.44 & 217.87 & 63.00 & 94.14 \\
\hline $\mathrm{P} 2 \mathrm{Y} 3 \times \mathrm{Y}$ & 16.95 & 185.97 & 3.87 & 32.96 & 207.93 & 67.00 & 28.39 \\
\hline $\mathrm{P} 2 \mathrm{~W} \times \mathrm{W} 1$ & 15.39 & 173.30 & 4.20 & 27.31 & 213.40 & 67.67 & 67.63 \\
\hline $\mathrm{P} 2 \mathrm{~W} \times \mathrm{W} 2$ & 16.38 & 162.15 & 3.85 & 24.64 & 189.73 & 68.00 & 27.14 \\
\hline $\mathrm{P} 2 \mathrm{~W} \times \mathrm{Y}$ & 14.61 & 135.97 & 3.72 & 23.06 & 183.27 & 69.67 & 94.35 \\
\hline P1Y1 & 20.48 & 174.90 & 4.11 & 25.33 & 201.47 & 68.33 & 184.31 \\
\hline P1Y2 & 17.93 & 169.10 & 3.98 & 24.49 & 207.60 & 69.00 & 274.91 \\
\hline P1Y3 & 19.54 & 172.21 & 4.33 & 25.23 & 186.67 & 69.67 & 226.48 \\
\hline P1W & 13.24 & 127.79 & 3.96 & 24.54 & 193.87 & 63.00 & 155.30 \\
\hline $\mathrm{P} 2 \mathrm{Y} 1$ & 14.71 & 139.43 & 3.81 & 24.70 & 159.93 & 74.00 & 128.37 \\
\hline $\mathrm{P} 2 \mathrm{Y} 2$ & 13.22 & 141.90 & 3.70 & 24.38 & 187.67 & 68.33 & 103.74 \\
\hline P2Y3 & 11.67 & 103.80 & 3.73 & 23.60 & 175.80 & 69.33 & 69.30 \\
\hline $\mathrm{P} 2 \mathrm{~W}$ & 17.57 & 188.43 & 3.98 & 28.74 & 188.47 & 66.00 & 61.79 \\
\hline W1 & 11.66 & 132.17 & 3.94 & 22.79 & 175.27 & 65.00 & 0.63 \\
\hline W2 & 14.02 & 156.13 & 3.88 & 22.36 & 174.73 & 62.00 & 1.04 \\
\hline Y & 14.50 & 131.90 & 3.72 & 23.44 & 164.07 & 74.00 & 1.46 \\
\hline Mean (F1) & 17.38 & 178.93 & 4.15 & 27.13 & 201.27 & 67.11 & 107.88 \\
\hline Range (F1) & $13.89-23.04$ & $135.97-212.42$ & $3.72-4.43$ & $21.64-32.96$ & $183.27-218.73$ & $62.33-74.33$ & $27.14-204.14$ \\
\hline Mean (L) & 16.04 & 152.20 & 3.95 & 25.13 & 187.68 & 68.46 & 150.52 \\
\hline Range (L) & $11.67-20.48$ & $103.8-188.43$ & $3.7-4.33$ & $23.6-28.74$ & $159.93-207.6$ & $63-74$ & $61.79-274.91$ \\
\hline Mean $(\mathrm{T})$ & 13.39 & 140.07 & 3.85 & 22.86 & 171.36 & 67.00 & 1.04 \\
\hline Range (T) & $11.66-14.5$ & $131.9-156.13$ & $3.72-3.94$ & $22.36-23.44$ & $164.07-175.27$ & $62-74$ & $0.63-1.46$ \\
\hline Best Lines & $\mathrm{P} 1 \mathrm{Y} 1, \mathrm{P} 1 \mathrm{Y} 2$ & P1Y1, P1Y2 & $\mathrm{P} 2 \mathrm{Y} 1, \mathrm{P} 1 \mathrm{Y} 2$ & $\mathrm{P} 2 \mathrm{Y} 3, \mathrm{P} 2 \mathrm{Y} 2$ & P1Y2, P1Y3 & $\mathrm{P} 2 \mathrm{Y} 1, \mathrm{P} 1 \mathrm{Y} 3$ & $\mathrm{P} 1 \mathrm{Y} 2, \mathrm{P} 1 \mathrm{Y} 1$ \\
\hline Best Testers & W1 & $\mathrm{W} 1, \mathrm{~W} 2$ & $\mathrm{Y}$ & W2 & $\mathrm{Y}$ & $\mathrm{W} 2$ & $\mathrm{~W} 2$ \\
\hline
\end{tabular}

\section{Heterosis}

The tendency of a hybrid to outperform its parent is referred to as the heterosis effect. In this section, we assess the ability to recognize the hybrid performance from the parent. According to Table 4, the heterosis analysis of FEY in both testers revealed that combining the P1Y2, P1W, and P2Y3 lines resulted in a significant positive heterobeltiosis. The highest heterobeltiosis is determined by $\mathrm{P} 2 \mathrm{Y} 2 \times \mathrm{Y}$, with values of $49.11 \%$. Except for the P2W $\times \mathrm{Y}$ combination, almost all $\mathrm{Y}$ tester combinations have significant positive heterosis. The SEW trait shows only 4 combinations generate positive significant positive values $(\mathrm{P} 1 \mathrm{~W} \times \mathrm{W} 1, \mathrm{P} 2 \mathrm{Y} 2 \times \mathrm{Y}, \mathrm{P} 2 \mathrm{Y} 3 \times \mathrm{W} 1, \mathrm{P} 2 \mathrm{Y} 3 \times \mathrm{Y})$. Except for seven combinations, all combinations of ED traits generate significant positive values of heterosis, namely $\mathrm{P} 1 \mathrm{Y} 3 \times \mathrm{W} 1, \mathrm{P} 1 \mathrm{~W} \times \mathrm{Y}, \mathrm{P} 2 \mathrm{Y} 3 \times \mathrm{W} 1, \mathrm{P} 2 \mathrm{~W} \times \mathrm{W} 2$, and $\mathrm{P} 2 \mathrm{~W}$ $\times \mathrm{Y}$. The $\mathrm{P} 2 \mathrm{Y} 1 \times \mathrm{Y}$ cross has the highest heterosis value for this trait, with a value of $15.35 \%$. The findings of the heterosis study on the NGR revealed that all combinations had significant positive values except for five, which were strongly negative: $\mathrm{P} 1 \mathrm{Y} 3 \times \mathrm{W} 2, \mathrm{P} 1 \mathrm{~W} \times \mathrm{W} 1, \mathrm{P} 2 \mathrm{~W} \times \mathrm{W} 1$, $\mathrm{P} 2 \mathrm{~W} \times \mathrm{W} 2$, and $\mathrm{P} 2 \mathrm{~W} \times \mathrm{Y}$. The combination of $\mathrm{P} 2 \mathrm{Y} 3 \times \mathrm{Y}$ crosses yielded the largest value of heterosis, with a value of almost $40 \%$. The heterosis values were slightly high in the hybrid, suggesting the hybrid had more NGR than their better parents. The $\mathrm{P} 2 \mathrm{Y} 2 \times \mathrm{W} 1$ and $\mathrm{P} 2 \mathrm{Y} 3 \times \mathrm{Y}$ combinations have significant negative heterobeltiosis values in the FEM trait. 


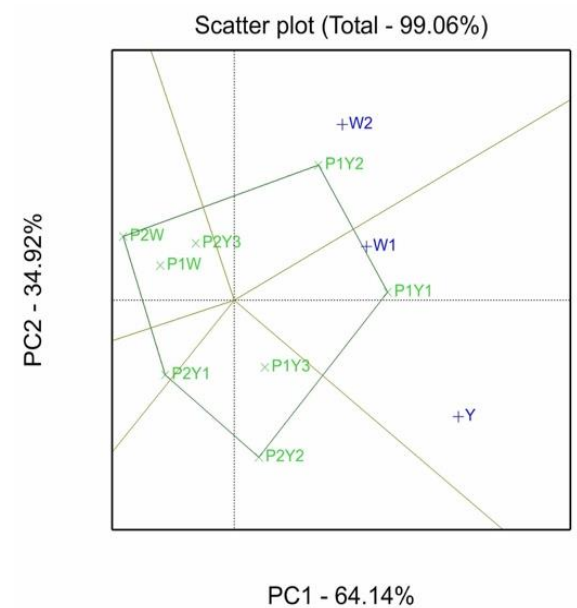

A

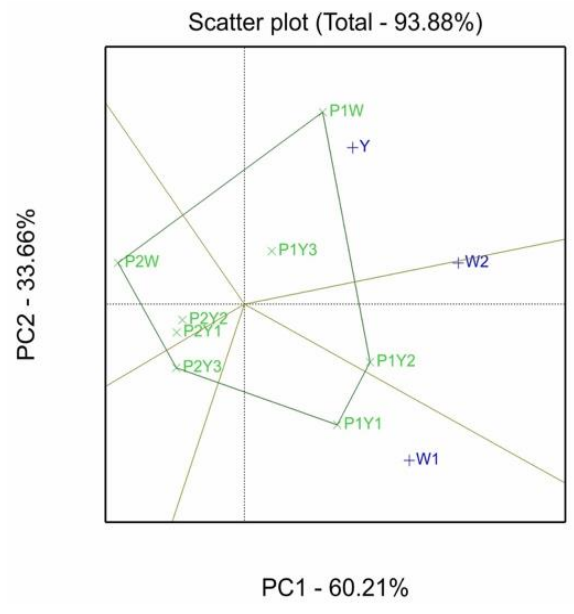

B

Figure 3. Scatter plot. Line (P-Y-) is in green and tester (W1, W2, Y) is in the blue letter. Traits are represented by the letter, A. FEY; B. Total Anthocyanin Content
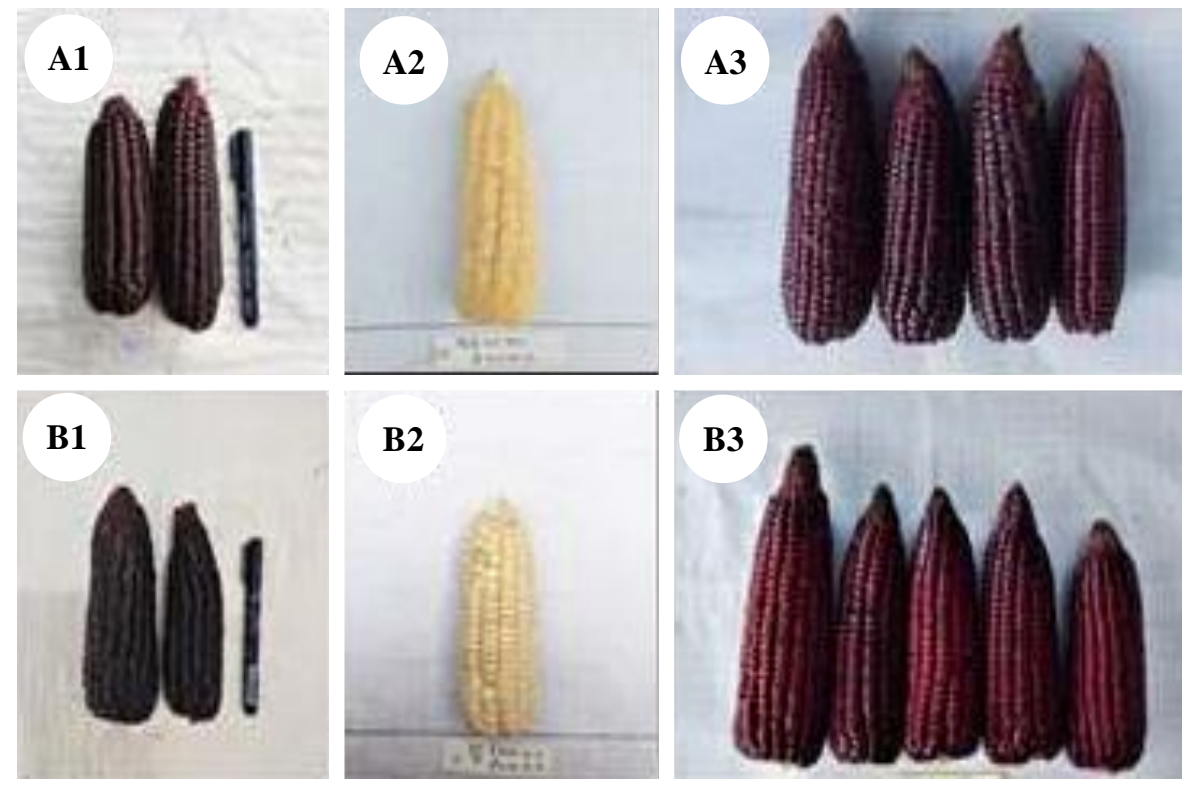

Figure 4. Ear samples of the best combination of F1 (hybrid); A. P1Y1 $\times$ W1; B. P1Y2 $\times$ W2; genotype represent by number: 1 . Lines, 2. Tester, 3. Hybrid

Only 3 of the 24 combinations have significant positive heterosis better than the better parent in TAC. This is probably due to the nature of the pericarp color gene which is partially dominant resulting in a decrease in the color intensity in the hybrid. This finding was confirmed by the ear color performance which can be seen in Figure 4. The hybrid (Figure 4.A3 and 4.B3) grain color was brighter than its parent (Figure 4.A1 and 4.B1). The P2Y3 $\times \mathrm{W} 1$, $\mathrm{P} 2 \mathrm{Y} 3 \times \mathrm{W} 2$, and $\mathrm{P} 2 \mathrm{~W} \times \mathrm{Y}$ combinations have higher TAC than the better parent. Although such combinations exhibit significantly substantial heterosis, this does not imply that the TAC is greater than in the other combinations; rather, it only demonstrates that the hybrid outperforms the better parent in terms of anthocyanin content. It also implies that the parent's TAC was lower than that of other lines.

\section{Discussion}

The total variance of each trait's main components ranged from $82.26 \%$ to $99.06 \%$ (Table 1). When the two main components explain more than $60 \%$ of the variability in the data and the total interaction effect accounts for more than $10 \%$ of the total variability, the two-way data variability in a GGE-Biplot study is said to be very good (Rakshit et al. 2012). According to Table 1, the variability of each trait approaches more than $60 \%$, indicating that the biplot graph generated may be used efficiently in understanding the potential of a line or its combination.

GGE-Biplot visualization may provide a clear image of the relationship between the line and the tester from various angles. Different graph readings may be used to determine lines, testers, and even the best combination 
(Ruswandi et al. 2015b). According to the mean performance (Table 3) and analysis of the GGE-biplot evaluation (Figure 3), some lines can be used as parents to produce superior purple corn hybrids. The P1Y2 line was selected as the best line based on five different characteristics: FEY, PH, ED, SEW, and TAC. The combination of this line and all testers produces a hybrid that outperforms the majority of hybrids (Table 3 ). The best hybrid using P1Y2 is P1Y2 $\times$ W2 which has not only a high yield (20.41 ton ha $\left.{ }^{-1}\right)$ but also has high anthocyanin content $\left(170.95 \mathrm{mg} 100 \mathrm{gr}^{-1}\right)$. This is supported by the heterosis level of the hybrid combination derived from this line, which is also significant in the FEY, ED, and NGR. While combinations involving P1W and P2Y3 have high heterosis among tested hybrids in the FEY trait, this may not imply that the hybrid is the best. This is because heterosis only shows how the hybrid will outperform the parents due to the heterotic effect. If the combination has high heterosis but no superiority, it means that the parents are equally low and the hybrid performance is close to that of an ordinary hybrid. The P1Y1 line was also selected as the best line based on FEY, SEW, and TAC traits. The best combination using P1Y1 is P1Y1 $\times \mathrm{W} 1$ which is also representing the strong characteristics of the best line. This combination not only has yield (19.31 ton ha-1) but also high TAC (204.14 mg 100-1) (Table 3), not to mention the FEM heterosis was negative which make this hybrid is early in maturity compare to its better parent although it is not significant (Table 4). The heterobeltiosis of TAC is significantly negative on identified best combination (Table
4) which confirm also in the mean performance (Table 3). This shows that the TAC of the hybrid will be lower than its better parent which has also been shown in the ear color performance with the reduction of color intensity (Figure 4). This finding also has been found in the previous study that used non-purple corn as a parent (Khamphasan et al. 2020).

Interestingly, the highest yield (FEY) was achieved by $\mathrm{P} 1 \mathrm{Y} 1 \times \mathrm{Y}\left(23.04\right.$ ton $\left.\mathrm{ha}^{-1}\right)$ and P1Y2 $\times \mathrm{W} 2\left(20.41\right.$ ton ha $\left.{ }^{-1}\right)$ with the lease tester (W2 and Y) instead of P1Y1 $\times \mathrm{W} 1$ (19.31 ton ha $^{-1}$ ) as P1Y1 line is considered the best lines and $\mathrm{W} 1$ as the best tester based on GGE-biplot evaluation (Table 3). This finding strengthens the previous study (Arifin et al. 2018), which demonstrates the best cross combinations displaying desirable yield components and grain yield performance have at least one parent with high significant GCAs.

Another line that excelled at two characteristics was the P1Y3 line, which was chosen as the best line for mediumlate maturity and high plant posture. It also shows on the $\mathrm{PH}$ trait that the heterosis value is not significant for all combinations, this is due to higher hybrid plant posture compared to its parents. According to previous studies, a strong correlation occurs between plant height and yield (Ram Reddy dan Jabeen 2016; Aman et al. 2020). High posture in corn can be said to be beneficial because it tends to give a higher yield. On the other hand, the impact of plant height on yield is indirect, implying that precaution is needed when determining the optimal plant height that can cause yield increase (Aman et al. 2020).

Table 4. Heterobeltiosis of yield and agronomic traits

\begin{tabular}{|c|c|c|c|c|c|c|c|}
\hline Hybrids & FEY & SEW & ED & NGR & PH & FEM & TAC \\
\hline $\mathrm{P} 1 \mathrm{Y} 1 \times \mathrm{W} 1$ & $-5,68 * *$ & 10.25 & $1,51 * *$ & $8,82 * *$ & 15,86 & $-0,51$ & 10,76 \\
\hline $\mathrm{P} 1 \mathrm{Y} 1 \times \mathrm{W} 2$ & $-7,14 * *$ & 8.59 & $5,52 * *$ & $3,73 *$ & 9,73 & $2,15 *$ & $-17,89$ \\
\hline $\mathrm{P} 1 \mathrm{Y} 1 \times \mathrm{Y}$ & $12,52 * *$ & 21.45 & $4,71 * *$ & $14,56 * *$ & $24,54 * *$ & $1,95 *$ & $-59,80 * *$ \\
\hline $\mathrm{P} 1 \mathrm{Y} 2 \times \mathrm{W} 1$ & $8,38 * *$ & 18.57 & $9,37 * *$ & $16,79 * *$ & $24,80 * *$ & $2,05 *$ & $-28,17$ \\
\hline $\mathrm{P} 1 \mathrm{Y} 2 \times \mathrm{W} 2$ & $13,86^{* *}$ & 17.58 & $6,47 * *$ & $3,40 *$ & 17,28 & $3,23 * *$ & $-37,81 *$ \\
\hline $\mathrm{P} 1 \mathrm{Y} 2 \times \mathrm{Y}$ & $6,84 * *$ & 21.45 & $10,80 * *$ & $21,46 * *$ & $28,52 * *$ & $-1,45$ & $-59,91 * *$ \\
\hline $\mathrm{P} 1 \mathrm{Y} 3 \times \mathrm{W} 1$ & $-11,04 * *$ & -10.24 & $-5,04 * *$ & $7,31 * *$ & $18,98 *$ & $-0,51$ & $-52,63 * *$ \\
\hline $\mathrm{P} 1 \mathrm{Y} 3 \times \mathrm{W} 2$ & $-21,01 * *$ & -0.26 & $2,25 * *$ & $-8,19 * *$ & 12,29 & $10,75 * *$ & $-37,79 *$ \\
\hline $\mathrm{P} 1 \mathrm{Y} 3 \times \mathrm{Y}$ & $4,01 *$ & 5.36 & $-0,84 * *$ & $12,37 * *$ & $25,44 * *$ & $5,74 * *$ & $-50,14 * *$ \\
\hline $\mathrm{P} 1 \mathrm{~W} \times \mathrm{W} 1$ & $18,58 * *$ & $39.45^{*}$ & $8,61 * *$ & $-11,82 * *$ & 16,09 & $2,65 * *$ & $-52,28 * *$ \\
\hline $\mathrm{P} 1 \mathrm{~W} \times \mathrm{W} 2$ & $16,79 * *$ & 13.71 & $7,81 * *$ & $6,38 * *$ & $20,41 *$ & $2,15 *$ & 20,03 \\
\hline $\mathrm{P} 1 \mathrm{~W} \times \mathrm{Y}$ & $11,09 * *$ & 17.89 & $-2,25 * *$ & $19,38 * *$ & 13,61 & $5,29 * *$ & 12,10 \\
\hline $\mathrm{P} 2 \mathrm{Y} 1 \times \mathrm{W} 1$ & $5,92 * *$ & 23.55 & $4,51 * *$ & $8,50 * *$ & $22,05 *$ & $3,08 * *$ & $-28,78$ \\
\hline $\mathrm{P} 2 \mathrm{Y} 1 \times \mathrm{W} 2$ & $-5,33 * *$ & 2.37 & $7,14 * *$ & $10,71 * *$ & $22,26 *$ & $8,06 * *$ & $-29,27$ \\
\hline $\mathrm{P} 2 \mathrm{Y} 1 \times \mathrm{Y}$ & $19,51 * *$ & 31.23 & $15,35 * *$ & $17,99 * *$ & $24,05 * *$ & 0,00 & $-62,44 * *$ \\
\hline $\mathrm{P} 2 \mathrm{Y} 2 \times \mathrm{W} 1$ & $20,88 * *$ & 25.60 & 0,02 & $20,60 * *$ & 7,42 & $-4,10 * *$ & $-8,85$ \\
\hline $\mathrm{P} 2 \mathrm{Y} 2 \times \mathrm{W} 2$ & $-0,91$ & -2.78 & $11,35 * *$ & $5,47 * *$ & $18,35 *$ & $4,30 * *$ & $-15,90$ \\
\hline $\mathrm{P} 2 \mathrm{Y} 2 \times \mathrm{Y}$ & $49,11 * *$ & $42.45^{*}$ & $3,94 * *$ & 2,46 & $19,50 *$ & $8,78 * *$ & $-40,44 *$ \\
\hline $\mathrm{P} 2 \mathrm{Y} 3 \times \mathrm{W} 1$ & $37,96 * *$ & $37.37 *$ & $-1,19 * *$ & $19,42 * *$ & 10,42 & $5,64 * *$ & $43,67 *$ \\
\hline $\mathrm{P} 2 \mathrm{Y} 3 \times \mathrm{W} 2$ & $24,86^{* *}$ & 17.33 & $6,20 * *$ & $24,74 * *$ & $24,69 * *$ & 1,61 & $35,84 *$ \\
\hline $\mathrm{P} 2 \mathrm{Y} 3 \times \mathrm{Y}$ & $16,85^{* *}$ & $40.99 *$ & $3,82 * *$ & $39,61 * *$ & $26,74 * *$ & $-3,37 * *$ & $-59,04 * *$ \\
\hline $\mathrm{P} 2 \mathrm{~W} \times \mathrm{W} 1$ & $-12,41 * *$ & -8.03 & $5,72 * *$ & $-4,99 * *$ & $21,76 *$ & $4,10 * *$ & 9,46 \\
\hline $\mathrm{P} 2 \mathrm{~W} \times \mathrm{W} 2$ & $-6,73 * *$ & -13.95 & $-3,22 * *$ & $-14,26 * *$ & 8,58 & $9,68 * *$ & $-56,08 * *$ \\
\hline $\mathrm{P} 2 \mathrm{~W} \times \mathrm{Y}$ & $-16,84 * *$ & -27.84 & $-6,35 * *$ & $-19,78 * *$ & 11,70 & $5,56 * *$ & $52,70 * *$ \\
\hline
\end{tabular}

Note: **: Significant level of 1\%, *: Significant level of 5\%; FEY: Fresh Ear Yield (ton ha' ${ }^{-1}$ ); SEW: Shelled Ear Weight (g); ED: Ear Diameter $(\mathrm{cm})$; NGR: Number of Grain Row ${ }^{-1}$; PH: Plant Height $(\mathrm{cm})$; FEM: Fresh Ear Maturity (Days After Planting); TAC: Total Anthocyanin Content $\left(\mathrm{mg} 100 \mathrm{~g}^{-1}\right)$ 
The best testers have also been identified using the GGE biplot analysis. The W2 tester has been identified as the best based on three traits: SEW, NGR, and TAC. There is also potential use of $\mathrm{W} 2$ as a tester if medium-late maturity is also taken into consideration. But, if the early maturity is preferred over the medium-late hybrid, then the use of the W2 tester should be considered and find a suitable line that will generate an early mature hybrid such as P1Y1 and P1Y2 (Table 3). The other two testers, W1 and $\mathrm{Y}$, were similarly superior in two traits: the W1 tester was superior in FEY and SEW, while tester Y was superior in PH (medium-high) and ED. The two testers have helped to form the best hybrids and identified several traits.

Since the biplot does not completely describe $100 \%$ of the total variation (Yan et al. 2002), some of the best combinations generated by GGE biplot analysis might have mismatching results. The P1Y1 $\times$ Y cross provided the maximum weight value of SEW, $212.42 \mathrm{~g}$, but this cross was not included in the best hybrid combination for this trait based on biplot analysis. This is because the biplot only accounts for $93.34 \%$ variation in the SEW trait in this analysis. Similarly, the combination of P2Y3 $\times$ W2 on the PH trait $(217.87 \mathrm{~cm})$ was the second-highest in this study where neither parent was included in the best category on $\mathrm{PH}$ traits. This is one of the biplot analysis's constrain (Yan et al. 2003). However, as previous research using the same approach has shown, this study, in general, can be a reliable technique for determining the ability of a plant genotype in hybrid development.

In conclusion, the GGE biplot can be used as a simple and efficient method for studying the combining ability of the best purple corn lines to form high-yielding purple corn hybrids. Purple corn line P1Y1 had the greatest GCA effect on yield traits, while P1Y2 had the greatest GCA effect on $\mathrm{ED}, \mathrm{SEW}$, and TAC, making it the best line based on the comparison plot type. The best tester was defined in the W1 tester based on the FEY and SEW characteristics. Some of the best combinations that can be identified from GGE biplot analysis are P1Y1 x W1, P1Y2 x W1, and $\mathrm{P} 1 \mathrm{Y} 2 \mathrm{x}$ W2. This combination is recommended because they have been identified as the best combination in several traits namely FEY, SEW, and TAC. Except for P1Y2 x $\mathrm{W} 1$, the other two combinations are also shorter in the plant posture. The best combination selected in this study is also generated from the best line and tester identified with GGE-biplot with the support of highly significant heterobeltiosis on FEY, ED, and NGR traits, except for P1Y1 x W1 that only have high heterobeltiosis in ED and NGR traits.

\section{ACKNOWLEDGEMENTS}

This research is part of the first author's thesis in the Graduate Program of the Faculty of Agriculture, Brawijaya University, Malang, Indonesia. The author would like to thank PT BISI International, Tbk for providing scholarships and research funds, and MRC (Maize Research Center) Brawijaya University for material support for this research.

\section{REFERENCES}

Ahmed MA, Abdelsatar MA, Attia MA, Abeer AA. 2019. GGE biplot analysis of line by tester for seed yield and its attributes in sunflower. Rudn J Agron Anim Ind 14 (4): 374-89. DOI: 10.22363/2312-797X2019-14-4-374-389

Aman J, Bantte K, Alamerew S, Sbhatu DB. 2020. Correlation and path coefficient analysis of yield and yield components of quality protein maize (Zea mays L.) hybrids at Jimma, Western Ethiopia. Int J Agron 2020: 9651537. DOI: 10.1155/2020/9651537

Arbha SW, Zeleke HZ, Gissa DW. 2013. Line x tester analysis of maize inbred lines for grain yield and yield related traits. Asian J Plant Sci Res 3 (5): 12-19.

Arifin NS, Nugraha AA, Waluyo B, Ardiarini NR, Azrai M. 2018. Grouping in heterotic pool of maize inbred lines based on numerical and graphical analysis of combining ability. Sabrao J Breed Genet 50 (4): 475-493.

Boonlertnirun K, Boonlertnirun S. 2018. Combining ability and group classifying of purple tian corn (Zea mays L .) inbred lines combining ability and group classifying of purple. Int J Adv Sci Eng Technol 6 (1): 36-41.

Georgiana MP, Muste S, Ranta O, Molnar A, Pacurar AD. 2019. Anthocyanins in maize (Zea mays): composition and health effects A Review. Hop Med Plants 27 (1-2): 50-56. DOI: $10.31883 /$ pjfns/113272

Harakotr B, Suriharn B, Lertrat K, Scott MP. 2016. Genetic analysis of anthocyanin content in purple waxy corn (Zea mays L. var. Ceratina Kulesh) kernel and cob. Sabrao J Breed Genet 48 (2): 230-239.

Hosana GC, Alamerew S, Tadesse B, Menamo T. 2015. Test cross performance and combining ability of maize (Zea mays L.) inbred lines at Bako, Western Ethiopia. Glob J Sci Front Res Agric Vet 15 (4): 1-24.

Hossain F, Bhat SR, Mohapatra T, Singh AK. 2019. Genetics on a maize cob: A teaching tool for schools. Indian J Genet Plant Breed 79 (01S): 340-366. DOI: 10.31742/ijgpb.79s.1.27

Kahriman F, Egesel CÖ, Orhun GE, Alaca B, Avci F. 2016. Comparison of graphical analyses for maize genetic experiments: Application of biplots and polar plot to line $\times$ tester design. Chil J Agric Res 76 (3): 285-293. DOI: 10.4067/S0718-58392016000300004

Kannababu N, Rakshit S, Madhusudhana R, Tonapi VA, Das IK, Raghunath K. 2017. Identification of superior parental lines for seed quality and storability through gge biplot analysis of line $\times$ tester data in grain sorghum. Indian J Genet Plant Breed 77 (2): 278. DOI: 10.5958/0975-6906.2017.00037.2

Khalil IA, Raziuddin R. 2017. Combining ability for seed yield in indigenous and exotic Brassica napus genotypes. Sarhad J Agric 33 (1): 177-182. DOI: 10.17582/journal.sja/2017.33.1.177.182

Khamphasan P, Lomthaisong K, Harakotr B, Scott MP, Lertrat K, Suriharn B. 2020. Combining ability and heterosis for agronomic traits, husk and cob pigment concentration of maize. Agric 10 (11): 1 19. DOI: 10.3390 /agriculture 10110510

Magaña-Cerino JM, Peniche-Pavía H A, Tiessen A, Gurrola-Díaz CM. 2020. Pigmented maize (Zea mays L.) contains anthocyanins with potential therapeutic action against oxidative stress - A Review. Pol J Food Nutr Sci 70 (2): 85-99. DOI: 10.31883/pjfns/113272

Momeni H, Shiri M, Hervan EM, Khosroshahli M. 2020. The usefulness of GGE biplot methodology for line $\times$ tester data of maize inbred lines. Bragantia 79 (4): 412-420. DOI: 10.1590/1678-4499.20200130

Moreno YS, Sánchez GS, Hernández DR, Lobato NR. 2005. Characterization of anthocyanin extracts from maize kernels. J Chromatogr Sci 43 (9): 483-487. DOI: 10.1093/chromsci/43.9.483

Mutimaamba C, MacRobert J, Cairns JE, Magorokosho C, Ndhlela T, Mukungurutse C, Minnaar-Ontong A, Labuschagne M. 2020. Line $\times$ tester analysis of maize grain yield under acid and non-acid soil conditions. Crop Sci 60 (2): 991-1003. DOI: 10.1002/csc2.20009

Rakshit S, Ganapathy KN, Gomashe SS, Rathore A, Ghorade RB, Kumar MVN, Ganesmurthy K, Jain SK, Kamtar MY, Sachan JS, Ambekar SS, Ranwa BR, Kanawade DG, Balusamy M, Kadam D, Sarkar A, Tonapi VA, Patil JV. 2012. GGE biplot analysis to evaluate genotype, environment and their interactions in sorghum multi-location data. Euphytica 185 (3): 465-479. DOI: 10.1007/s10681-012-0648-6

Ram Reddy V, Jabeen F. 2016. Narrow sense heritability, correlation and path analysis in maize (Zea mays L.). Sabrao J Breed Genet 48 (2): 120-126. 
Ruswandi D, Supriatna J, Makkulawu AT, Waluyo B, Marta H, Suryadi E, Ruswandi S. 2015a. Determination of combining ability and heterosis of grain yield components for maize mutants based on linextester analysis. Asian J Crop Sci 7 (1): 19-33. DOI: 10.3923/ajcs.2015.19.33

Ruswandi D, Supriatna J, Waluyo B, Makkulawu AT, Suryadi E, Chindy ZU. 2015b. GGE biplot analysis for combining ability of grain yield and early maturity in maize mutant in Indonesia. Asian J Crop Sci 7 (3): 160-173. DOI: 10.3923/ajcs.2015.160.173

Singh RK, Chaudary BD. 1977. Biometrical Methods in Quantitative Genetic Analysis. Kalyani.
Sutharut J, Sudarat J. 2012. Total anthocyanin content and antioxidant activity of germinated colored rice. Int Food Res J 19 (1): 215-221.

Yan W. 2001. GGE biplot-a windows application for graphical analysis of multienvironment trial data and other types of two-way data. Agron J 93 (5): 1111-118. DOI: 10.2134/agronj2001.9351111x

Yan W, Hunt LA. 2002. Biplot analysis of diallel data. Crop Sci 42 (1): 21-30. DOI: $10.2135 /$ cropsci2002.0021

Yan W, Kang MS. 2003. GGE Biplot Analysis A Graphical Tool for Breeders, Geneticists, and Agronomists. CRC Press, Boca Raton, Florida. 